\title{
Production, fertility, survival, and body measurements of Montbéliarde-sired crossbreds compared with pure Holsteins during their first 5 lactations
}

\author{
A. R. Hazel, ${ }^{1}$ B. J. Heins, A. J. Seykora, and L. B. Hansen \\ Department of Animal Science, University of Minnesota, St. Paul 55108
}

\begin{abstract}
Two-breed crossbreds of Montbéliarde and Holstein $(\mathrm{MO} \times \mathrm{HO})$ as well as 3-breed crossbreds of Montbéliarde and Jersey/Holstein $(\mathrm{MO} \times \mathrm{JH})$ were compared with pure Holstein (HO) cows for production, somatic cell score (SCS), fertility, survival to subsequent calving, mortality, and body measurements during their first 5 lactations. Cows calved for the first time between 2005 and 2010 and were housed in either a confinement herd or a herd that had access to pasture for $165 \mathrm{~d}$ of the year in the north central region of the United States. Body, hoof, and udder measurements of cows were also objectively measured. The $\mathrm{MO} \times \mathrm{HO}$ crossbred cows were not different from pure HO cows for fat-plus-protein production during any lactation. However, the MO $\times \mathrm{JH}$ crossbred cows had $5 \%$ lower fat-plus-protein production compared with pure $\mathrm{HO}$ cows in the confinement herd. On the other hand, the $\mathrm{MO} \times \mathrm{JH}$ crossbred cows were not different for fatplus-protein production in the third to fifth lactation compared with pure $\mathrm{HO}$ cows in the seasonal pasture herd. Across the 2 herds, the $\mathrm{MO} \times \mathrm{HO}$ and $\mathrm{MO} \times \mathrm{JH}$ crossbred cows had $21 \%$ higher first-service conception rate, 41 fewer days open, and $12 \%$ higher pregnancy rate compared with the pure $\mathrm{HO}$ cows. Furthermore, the $\mathrm{MO} \times \mathrm{HO}(5 \%)$ and $\mathrm{MO} \times \mathrm{JH}(12 \%)$ crossbred cows had lower mortality rates than the pure HO cows $(18 \%)$. Because of superior fertility and lower mortality rates, the $\mathrm{MO} \times \mathrm{HO}$ and $\mathrm{MO} \times \mathrm{JH}$ crossbred cows, combined, had greater survival to second $(+13 \%)$, third $(+24 \%)$, fourth $(+25 \%)$, and fifth $(+17 \%)$ lactation compared with pure $\mathrm{HO}$ cows. For body measurements, $\mathrm{MO} \times \mathrm{HO}$ were similar to pure $\mathrm{HO}$ cows for hip height and heart girth, but $\mathrm{MO} \times \mathrm{HO}$ cows had more body condition and greater body weight $(+39$ $\mathrm{kg}$ ) across the first 5 lactations. The $\mathrm{MO} \times \mathrm{JH}$ cows had more body condition but $5 \mathrm{~cm}$ shorter hip height and $28 \mathrm{~kg}$ less body weight than pure HO cows across the first 5 lactations. Foot angle was steeper and hoof
\end{abstract}

Received May 24, 2013.

Accepted December 20, 2013.

${ }^{1}$ Corresponding author: haze0025@umn.edu length was shorter for $\mathrm{MO} \times \mathrm{HO}$ cows, but $\mathrm{MO} \times \mathrm{JH}$ cows were similar to pure HO cows for hoof measurements.

Key words: crossbreeding, Montbéliarde, fertility, survival

\section{INTRODUCTION}

Through modern history, milk has traditionally been produced by purebred dairy cows from localized breeds in most places of the world. In recent decades, sophisticated, long-term selection strategies have resulted in a rapid increase of milk production for the Holstein (HO) breed (Miglior et al., 2005), and pure HO cows now predominate in most temperate regions of the world. A genetic monoculture of only pure HO cows has the potential of becoming detrimental to the fitness and viability of cows as increased genetic relationships within the breed result from highly effective selection programs.

Simultaneous selection for increased angularity and larger body size (Leitch, 1994; Hansen, 2000; Shook, 2006; Henderson et al., 2011), in conjunction with selection for production, has exacerbated a decline in fertility, health, and survival of pure HO cows (Lucy, 2001; Roche et al., 2009). Deterioration of health traits may also result from continuous increases of inbreeding (Sørensen et al., 2005; Bjelland et al., 2013), which is about $6.1 \%$ for US Holstein cows born in 2013 (Council on Dairy Cattle Breeding, 2013). As a consequence, dairy producers are exploring systems of crossbreeding to improve the robustness, efficiency, and profitability of dairy cows (Weigel and Barlass, 2003).

Heterosis results from the interaction of heterozygous genes at loci, so the performance of offspring is greater than the average of parents, and heterosis has a major effect on health and fertility traits (Falconer and Mackay, 1996). The largest amount of heterosis is achieved when mating individuals from unrelated breeds (Hansen, 2006). Most producers of beef cattle, pig, sheep, and poultry have embraced the routine use of heterosis for their commercial production systems for at least $50 \mathrm{yr}$, and the desire to boost animal performance via heterosis has necessitated the ongoing stewardship 
of multiple breeds or inbred lines for those types of farm animals. Dependence on the routine crossing of breeds or inbred lines eliminates the concern regarding negative consequences of inbreeding depression for the commercial sector. In contrast, the majority of dairy producers have instead chosen to invest in labor-intensive and costly management inputs rather than relying on heterosis to mitigate health problems and impaired fertility of dairy cows.

The economic benefit of crossbreeding has been documented over the past $15 \mathrm{yr}$ in a variety of management systems for commercial milk production (VanRaden and Sanders, 2003; Dillon et al., 2007; Pyman, 2007; Sørensen et al., 2008; Heins et al., 2012a). Specifically, the performance and profitability of 2-breed crossbred cows during multiple lactations have been reported for combinations of HO, Jersey, and Brown Swiss, which are familiar breeds in North America (VanRaden and Sanders, 2003; Heins et al., 2011, 2012b). Inevitably, producers must decide how to mate 2-breed crossbred cows, and a backcross to 1 of the 2 parental breeds results in a $50 \%$ reduction of heterosis compared with that of 2-breed crossbreds. Lopez-Villalobos et al. (2000) observed that 3-breed rotational crossbreeding systems could increase profitability for commercial milk production in New Zealand. The use of 3 breeds is necessary to maintain high average levels of heterosis across generations, and the 3 breeds should be used in a rotational mating pattern (Hansen, 2006). Assessing the performance of 3-breed crossbred cows is a high priority for research into the future, because few crossbreeding studies have assessed performance of the second generation of a rotational crossbreeding system across various management systems.

Some dairy cattle breeds that have been regarded as foreign to the United States are being used for crossbreeding (Swalve, 2007; Sørensen et al., 2008), because some of these breeds offer strength for traits that are lacking in the traditional US dairy breeds. In particular, the Montbéliarde (MO) breed has generated substantial interest for crossbreeding in recent years, and research has documented that milk, fat, and protein production of $\mathrm{MO} \times \mathrm{HO}$ cows is similar to or slightly lower (ranging from 0 to $-3 \%$ ) than that of pure $\mathrm{HO}$ cows (Walsh et al., 2008; Heins and Hansen, 2012; Heins et al., 2012a). Furthermore, the superiority of MO $\times$ HO cows for SCS, fertility, and longevity may contribute to the greater profitability of MO-sired crossbreds ( $+5 \%$; Heins et al., 2012a) compared with pure HO cows. Mendonça et al. $(2010,2013)$ documented greater innate immune response for MO-sired crossbred versus pure $\mathrm{HO}$ cows as well as a lower incidence of postpartum disease for MO-sired (35\%) crossbreds versus pure HO $(57 \%)$ cows.
Reports of body measurements for MO-sired crossbred cows are sparse, yet some dairy producers focus attention on conformation when evaluating crossbred cows. Walsh et al. (2008) and Hazel et al. (2013) both reported greater $\mathrm{BCS}$ for $\mathrm{MO} \times \mathrm{HO}$ versus pure $\mathrm{HO}$ cows across lactations. Differences for BW were nonexistent according to Walsh et al. (2008) and greater for $\mathrm{MO} \times \mathrm{HO}$ cows compared with pure $\mathrm{HO}$ cows $(+36$ $\mathrm{kg}$ ) according to Hazel et al. (2013). Neither of these studies included measurements of udders or feet and legs of cows.

The objectives of this study were to compare the phenotypic performance of MO-sired crossbred and pure HO cows. The phenotypic traits compared were production, SCS, first-service conception rate (CR), days open (DO), pregnancy rate (PR), mortality rate, survival (to second, third, fourth, and fifth calvings), longevity, and body measurements during the first 5 lactations.

\section{MATERIALS AND METHODS}

\section{Experimental Design}

A crossbreeding experiment was initiated in 2000 for 2 research dairy herds at the University of Minnesota, and the 2 herds had historically used the same service sires to breed cows for many generations. The design of the experiment was thoroughly reviewed in Heins et al. (2010). The confinement herd at the St. Paul campus of the University of Minnesota had 90 tie-stalls and a 40-head loose-housing barn with TMR feeding (Table 1). The seasonal pasture herd was located at the West Central Research and Outreach Center (Morris, MN) and had 180 milking cows. The seasonal pasture herd was fed a TMR diet during the entire year; however, the summer TMR diet contained less forage because cows consumed approximately $35 \%$ of their diet from pasture for the 165-d pasture period, which spanned from May to October (Table 1). Winters are extremely harsh in Minnesota, without potential for access to pasture for 6 mo of each year (November to April). Cows in the seasonal pasture herd were stocked at a rate of 3.1 cows/ha and were rotated to other paddocks as availability of grass was depleted.

Cows in this study were sired either by $\mathrm{MO}$ or $\mathrm{HO}$ AI bulls. Bull selection was based on high rank for the French total merit index [Index de Synthèse UPRA (ISU); O. S. Montbéliarde, 2013] for MO bulls and the US net merit index (Cole et al., 2009b) for HO bulls. The same 3 MO bulls were selected annually for use in both herds, and they were always among the top 10 proven AI bulls in France for the ISU index. Likewise, $3 \mathrm{HO}$ bulls were selected annually for use in both herds 
Table 1. Constituents of diets for the confinement herd (St. Paul, MN) and the seasonal pasture herd (Morris, $\mathrm{MN}$ ) on a DM basis

\begin{tabular}{|c|c|c|c|}
\hline \multirow[b]{2}{*}{$\begin{array}{l}\text { Constituent } \\
(\%, \text { unless otherwise noted })\end{array}$} & \multirow[b]{2}{*}{$\begin{array}{l}\text { Confinement herd } \\
\text { (TMR diet) }\end{array}$} & \multicolumn{2}{|c|}{ Seasonal pasture herd } \\
\hline & & $\begin{array}{l}\text { Winter diet } \\
\text { (TMR only) }\end{array}$ & $\begin{array}{c}\text { Summer diet } \\
\text { (TMR plus pasture) }\end{array}$ \\
\hline $\mathrm{NE}_{\mathrm{L}}(\mathrm{Mcal} / \mathrm{kg}$ of $\mathrm{DM})$ & 1.70 & 1.59 & 1.59 \\
\hline $\mathrm{CP}(\%$ of $\mathrm{DM})$ & 18.0 & 16.4 & 19.6 \\
\hline Corn silage & 39.7 & 37.0 & 20.2 \\
\hline Alfalfa silage & - & 16.4 & - \\
\hline Chopped alfalfa hay & 15.6 & - & - \\
\hline Pasture & - & - & 34.9 \\
\hline Chopped straw & - & 4.2 & 4.5 \\
\hline Ground corn & 12.6 & 25.3 & 22.4 \\
\hline Distillers grains & - & 9.6 & 9.1 \\
\hline Soybean meal & 11.4 & 5.5 & 7.2 \\
\hline Protein by-products ${ }^{1}$ & 11.7 & - & - \\
\hline
\end{tabular}

${ }^{1}$ Protein by-products included soybean hulls, bypass protein, corn gluten meal, and blood meal.

that ranked among the top $5 \%$ of proven bulls in the US for the net merit index, and 93\% of the cows in this study were daughters of HO bulls selected in this manner. However, $7 \%$ of pure $\mathrm{HO}$ cows in this study were sired by unproven AI bulls without daughters contributing to their PTA, because a small number of pure $\mathrm{HO}$ cows that had difficulty in conception in the seasonal pasture herd were bred to unproven AI bulls for fourth-or-later AI services. In total, the $150 \mathrm{MO}$ sired crossbred cows were sired by $12 \mathrm{MO}$ AI bulls and the 163 pure HO cows were sired by 27 HO AI bulls. Dams of cows were either pure HO cows or Jersey $x$ HO crossbred (JH) cows, and dams of cows were sired by high-ranking (top 5\%) AI bulls for the net merit index in the United States for both the HO and Jersey breeds at the time of selection.

All cows in the confinement herd began first lactation during fall seasons (October to January) for 5 years (2005 to 2009). Most cows in the confinement herd ( $84 \%$ of lactations) calved for subsequent lactations during fall seasons from October to February and were assigned to $7 \mathrm{yr}$ of calving from 2006 to 2012. In the seasonal pasture herd, all cows calved for the first time during spring seasons (March to June) for $5 \mathrm{yr}$ (2006 to 2010). The majority of multiparous cows in the seasonal pasture herd subsequently calved during spring ( $68 \%$ of lactations), but fall-calving multiparous cows $(32 \%$ of lactations) were combined with cows from the previous spring to create $6 \mathrm{yr}$ of calving (March to December) from 2007 to 2012. Data collection spanned the period from October 2005 to February 2013, except body measurements ended in February 2012.

Table 2 has number of cows initiating first lactation in each herd by calving year and breed group. The mean age of first calving in the confinement herd for MO-sired crossbred and pure $\mathrm{HO}$ cows was $24.3 \pm 0.3$ mo and $24.4 \pm 0.3 \mathrm{mo}$, respectively. In the seasonal pasture herd, mean age of first calving was $23.8 \pm 0.2$ mo for MO-sired crossbred cows and $24.7 \pm 0.3$ mo for pure $\mathrm{HO}$ cows.

Cows in the confinement herd were synchronized with a timed AI protocol for both first and later services during a 6-mo concentrated breeding season. Despite efforts to calve seasonally, some cows calved outside of target calving periods because managers in the confinement herd bred some cows from standing heats after the designated breeding period in years when fertility was particularly poor. Cows in the seasonal pasture herd were synchronized with prostaglandin, and $90 \%$ of cows were bred as a result of standing heat following either a first or second prostaglandin injection. The $10 \%$ of cows not bred from prostaglandin were enrolled in a timed synchronization protocol. Subsequent AI services in the seasonal pasture herd were also synchronized, and breeding seasons consisted of two 3-mo periods in late winter and late summer.

Managers of the 2 herds culled cows only involuntarily, except 8 cows were voluntarily sold in the seasonal pasture herd during third lactation or greater during the final year of the study. Cows in the confinement herd were allowed at least 6 mo of opportunity to become pregnant before a decision to cull was made. On the other hand, cows in the seasonal pasture herd were strictly culled if they did not become pregnant within 2 breeding seasons (6 mo of opportunity).

\section{Production and SCS}

Monthly test-day observations for twice-daily milking from milk recording (DHI) were used to estimate production. Standard edits used by the US Department of Agriculture for routine genetic evaluations were ap- 
Table 2. Number of cows by herd, year, and breed group for first calving

\begin{tabular}{lccc}
\hline & \multicolumn{3}{c}{ Breed } \\
\cline { 2 - 4 } Item & $\begin{array}{c}\text { Pure } \\
\text { Holstein }\end{array}$ & $\begin{array}{c}\text { Montbéliarde } \\
\times \text { Holstein }\end{array}$ & $\begin{array}{c}\text { Montbéliarde } \\
\times \text { Jersey/Holstein }\end{array}$ \\
\hline Confinement herd (St. Paul, MN) & & & \\
2005 & 12 & 14 & 1 \\
2006 & 14 & 12 & 13 \\
2007 & 16 & 7 & 14 \\
2008 & 14 & 0 & 6 \\
2009 & 20 & & 8 \\
Seasonal pasture herd (Morris, MN) & 18 & 7 & 16 \\
2006 & 17 & 1 & 7 \\
2007 & 20 & 3 & 4 \\
2008 & 13 & 1 & 91 \\
2009 & 19 & 59 & \\
Total & 163 & & \\
\hline
\end{tabular}

plied to test-day observations and were discussed in Hazel et al. (2013). The 305-d production and SCS was calculated with best prediction (Cole et al., 2009a), using all available individual test-day records for milk $(\mathrm{kg})$, fat $(\mathrm{kg})$, and protein $(\mathrm{kg})$ production and SCS. Records less than 305 d were projected to 305 d, including records of cows with completed lactations of less than $305 \mathrm{~d}$.

To estimate production and SCS, cows were required to have at least 1 test day, and 25 lactations of cows (11 MO-sired crossbred and 14 pure HO) without a test day were removed for analysis of production and SCS. Furthermore, 23 cows experienced spontaneous abortion, and the affected lactations (13 MO-sired crossbred and 10 pure HO) were also excluded from analysis for production and SCS. Lactations were assigned to groups of first, second, or third to fifth. At least 2 cows were required per breed of sire (MO-sired crossbred or pure $\mathrm{HO}$ ) within each combination of herd, lactation number, year of calving, and breed of sire, and this stipulation removed 1 pure HO in second lactation and 3 MO-sired and 1 pure $\mathrm{HO}$ cow from third to fifth lactation.

Independent variables for the statistical analysis of 305-d milk, fat, and protein production, fat-plusprotein production, and SCS were the fixed effects of herd, lactation number, interaction of herd and lactation number, year of calving nested within interaction of herd and lactation number, breed of sire, $\mathrm{MO} \times$ $\mathrm{HO}$ versus $\mathrm{MO} \times \mathrm{JH}$ nested within $\mathrm{MO}$ breed of sire (henceforth referred to as breed group), interaction of herd and breed group, interaction of lactation number and breed group, and 3-way interaction of herd, lactation number, and breed group. Lactational records were preadjusted for age at calving with best prediction. The MIXED procedure of SAS (SAS Institute, 2008) was used to conduct the ANOVA and to obtain solutions, and cow nested within breed group was defined as a random variable.

\section{Fertility}

The CR was defined as the proportion of cows that became pregnant divided by the cows that were inseminated for the first time during each of their first 5 lactations. The result of first breeding was determined by (1) subsequent breeding, (2) palpation, or (3) subsequent calving. Cows that did not remain in the herd to be either rebred or palpated after first breeding were excluded from the analysis $(n=8)$. Similar to the production analysis, 2 cows were required per combination of herd, lactation number, year of calving, and breed of sire, and $1 \mathrm{MO}$-sired crossbred in third-to-fifth lactation and 1 pure HO cow in second lactation were removed, which resulted in 707 observations for CR available for analysis. Independent variables for the statistical analysis of CR were the same as those for analysis of production and SCS. A preliminary model included DIM at first breeding; however, the linear effect was not significant $(P=0.96)$ and, therefore, DIM was removed from the final analysis. The MIXED procedure of SAS was used to obtain the least squares means and the LOGISTIC procedure was used to determine significance of contrasts because CR was a binary trait.

The 599 observations for DO consisted of days from calving to pregnancy and all pregnancies were verified by palpation and, when possible, by subsequent calving $(\mathrm{n}=487)$. Cows with DO greater than $250 \mathrm{~d}(\mathrm{n}=131)$ were set to $250 \mathrm{~d}$ (VanRaden et al., 2004), which is the method used for genetic evaluation in the United States. This maximum of $250 \mathrm{~d}$ favored the pure HO cows, because $34 \%$ of pure HO cows surpassed 250 
DO whereas only $12 \%$ of MO-sired crossbred cows surpassed 250 DO. Cows were required to complete at least 250 DIM (VanRaden et al., 2004), and the number of observations for DO was less than observations for CR because 103 cows were bred at least once but did not remain in the herd for $250 \mathrm{~d}$. Two cows were required per combination of herd, lactation number, year of calving, and breed of sire, and $6 \mathrm{MO}$-sired crossbred and 1 pure $\mathrm{HO}$ cow in second lactation were removed. Independent variables and methods for the statistical analysis of DO were the same as those used for analysis of production and SCS.

The PR is a group statistic used heavily in the United States for herd management and is defined as the number of cows that became pregnant divided by the number of cows eligible to become pregnant, where the denominator equals the cumulative days at risk for pregnancy divided by 21 (the length of an average estrous cycle; de Vries et al., 2005). To be included in the analysis of PR, cows were required to reach the end of the voluntary waiting period in their respective herd (57 DIM for the confinement herd and 60 DIM for the seasonal pasture herd). Days at risk was defined as days from the end of the voluntary waiting period for first breeding to (1) pregnancy, (2) decision to cull, or (3) exiting the herd. The numbers of lactational records analyzed for PR are different from DO, because PR includes cows that were culled or died between the end of the voluntary waiting period and 250 DIM. The PR was calculated independently for each combination of lactation number and breed group, and the PR for breed groups across lactations was also computed independently. The LIFETEST procedure of SAS was used to determine statistical significance of PR for breed groups within and across lactation number.

\section{Mortality Rate and Survival}

Mortality rate was defined as the number of cows that died or were euthanized divided by the total number of cows. Mortality was recorded in a binary manner as died (1) or sold (0), and cows coded as died also included cows that were euthanized. Seven MO-sired crossbreds and 10 pure $\mathrm{HO}$ cows were removed from the survival analysis because they did not spend their entire lives in 1 herd. Nine of these 17 cows were transferred from the seasonal pasture herd to the confinement herd after completion of either first or second lactation, and the other 8 cows were in third-or-later lactation in the seasonal pasture herd and were sold for dairy purposes. After exclusion of these 17 cows, $57 \mathrm{MO} \times \mathrm{HO}, 86 \mathrm{MO}$ $\times \mathrm{JH}$, and 153 pure $\mathrm{HO}$ cows remained for analysis of mortality rate. The analysis of mortality rate included 7 MO-sired crossbred and 6 pure $\mathrm{HO}$ cows that were still in the herds at the cutoff of data for this study, and all of these cows were in fourth lactation or greater. These 13 cows were credited as eventually being sold alive, although their final status was unknown.

Independent variables for mortality rate included the effects of herd, breed of sire, breed group, and interaction of herd and breed group. The GLM procedure of SAS was used to obtain least squares means, and the LOGISTIC procedure of SAS was used to determine significance of contrasts because mortality rate was a binary trait.

Data for survival were recorded in a binary manner as calved (1) or did not calve (0) for a second, third, fourth, or fifth time. The 17 cows removed from the mortality analysis were also removed from the survival analysis. All cows were provided an opportunity to calve a third time, but some cows did not have an opportunity to calve a fourth or fifth time because data collection ceased in February 2013. Four MO-sired crossbreds and 17 pure $\mathrm{HO}$ did not have an opportunity to calve a fourth time. Additionally, $15 \mathrm{MO}$-sired crossbreds and 33 pure HO cows did not have an opportunity to calve a fifth time and, therefore, those cows were removed from the analysis for survival to fourth or fifth calving.

Independent variables for survival to subsequent calving included the effects of herd, breed of sire, breed group, and interaction of herd and breed group, and the GLM procedure of SAS was used to obtain least squares means. The LOGISTIC procedure of SAS was used to determine significance of contrasts for breed groups.

\section{Longevity and Lifetime Production}

The 17 cows removed from the mortality and survival analyses were also removed from the longevity and lifetime production analysis because they did not complete their entire lives in a single herd. Longevity during the first 4 yr $(1,461 \mathrm{~d})$ in the herd was defined as the total number of days in the herd from first calving to either (1) exiting the herd or (2) remaining in the herd at 1,461 d after first calving. Nineteen MO-sired crossbreds and 50 pure $\mathrm{HO}$ cows were removed from the analysis of longevity and lifetime production because data collection ceased in February 2013, and these cows did not have an opportunity to remain in the herds for 4 yr. A 4-yr maximum was imposed because almost all cows in this study had the opportunity to remain in the herd for $4 \mathrm{yr}$, and cows surviving beyond $4 \mathrm{yr}(28 \%$ of $\mathrm{MO} \times \mathrm{HO}, 23 \%$ of $\mathrm{MO} \times \mathrm{JH}$, and $16 \%$ of pure $\mathrm{HO}$ cows) were assigned a maximum of $1,461 \mathrm{~d}$ of longevity. The exclusions resulted in $53 \mathrm{MO} \times \mathrm{HO}, 71 \mathrm{MO} \times \mathrm{JH}$, and 103 pure HO cows available for analysis of longevity and lifetime production across both herds. 
For lifetime production, daily fat and protein production was calculated from best prediction for complete lactations (up to 999 DIM) using all available test days from milk recording. Cows with lactations shorter than $305 \mathrm{~d}$ were not projected to $305 \mathrm{~d}$, and all production beyond $305 \mathrm{~d}$ was included. Daily production of fat and protein was summed across lactations, and days in the dry period were assigned $0 \mathrm{~kg}$ of production. Daily production of fat and protein beyond 1,461 d was excluded from the summed lifetime production.

The statistical analysis of longevity and lifetime fatplus-protein production had independent variables of herd, breed of sire, breed group, and interaction of herd and breed group as fixed effects. The GLM procedure of SAS was used to conduct the ANOVA and obtain least squares means.

\section{Body Measurements}

Trait Descriptions. The hip height (HH) was objectively measured from the ground to the sacrum, and measurements were obtained while cows were standing either in their stalls or in a chute. Cows in the confinement herd had $\mathrm{HH}$ measured once per lactation between 4 and 272 DIM. However, cows in the seasonal pasture herd were measured monthly throughout lactation. Observations in the seasonal pasture herd before 4 DIM and after 272 DIM were discarded, and the remainder of $\mathrm{HH}$ observations (up to 10 per cow) was averaged for each cow, resulting in $1 \mathrm{HH}$ observation per lactation for each cow. The BCS was recorded by the same person within each combination of year of calving and herd on a 1 -to- 5 scale $(1=$ thin and $5=$ obese $)$ in increments of 0.25 (Ferguson et al., 1994). The BW and BCS were recorded during the p.m. milking every other week in the confinement herd between October 2005 and September 2008 and monthly thereafter. In the seasonal pasture herd, BW and BCS were recorded monthly during the a.m. milking for the entire collection period. Measurements for BW and BCS between 90 and 225 DIM were averaged for each cow, and this resulted in a single observation per lactation. To assess change in BW and BCS during lactations for breed groups, all available BW and BCS measurements from day of calving to 300 DIM were assigned to 30-d intervals ( 1 to $30 \mathrm{~d}, 31$ to $60 \mathrm{~d}, 61$ to $90 \mathrm{~d}$, and so on), which resulted in up to 10 observations per cow that spanned the first $300 \mathrm{~d}$ of lactation. Measurements of heart girth (HG) were obtained once per lactation in both herds and were from 4 to 288 DIM.

Foot angle (FANGL) and hoof length (HL) were collected from the lateral claw of the rear hoof once per lactation while cows were standing on a level, concrete surface. The FANGL and HL were both measured on the dorsal abaxial wall between the periople line and the point of toe (Hahn et al., 1984). The FANGL was the slope, and HL was the greatest distance between the periople line and the point of toe. Measurements for FANGL and HL were from 9 to 288 DIM, except for only 3 cows that calved late in the year of calving and were measured after 305 DIM.

Udder clearance (UC), front teat width (TW), and front teat length (TL) were objectively measured once per lactation. The UC was the distance between the lowest point of the udder floor and the ground, and TW was the inner distance between the front teats. The TL was the length of the front teat, unless TL appeared noticeably different between the 2 front teats. In that case, the length of both front teats was averaged to obtain a single TL measurement. All cows within each year of calving had udders measured within the same 3 -h period relative to previous milking. Udders were measured from 4 to $288 \mathrm{DIM}$, except for $1 \mathrm{MO} \times \mathrm{JH}$ and 1 pure $\mathrm{HO}$ cow that calved late in their respective year of calving and were measured after 305 DIM.

Editing and Analysis. Lactations from 3 to 5 were combined into a single lactation group for analysis, and observations in sixth-and-greater lactations were excluded for the analysis of all 9 body measurements. Additionally, $1 \mathrm{MO}$-sired crossbred and 1 pure $\mathrm{HO}$ cow in first lactation had HG observations beyond 305 DIM, and those 2 observations for HG were removed from the data. Cows were assigned to years of calving, and at least 2 cows per combination of herd, lactation number, year of calving, and breed of sire were required. Therefore, 1 pure $\mathrm{HO}$ cow in second lactation (for all 9 body measurements) and another $10 \mathrm{MO}$-sired crossbred and 1 pure $\mathrm{HO}$ cows from third-to-fifth lactation (only for HG, FANGL, HL, UC, TW, and TL) were removed from the data.

Statistical analysis for all 9 body measurements had the fixed effects of herd, lactation number, interaction of herd and lactation number, year of calving nested within interaction of herd and lactation number, breed of sire, breed group, interaction of herd and breed group, interaction of lactation number and breed group, and 3 -way interaction of herd, lactation number, and breed group. Cow nested within breed group was defined as a random variable. A preliminary model considered the linear effect of DIM at time of measurement; however, this effect was not significant $(P>0.05)$ for $\mathrm{HH}$, BW, BCS, HG, HL, and TL and was removed from all models so that a consistent model could be used for all 9 body measurement analyses. The MIXED procedure of SAS was used to conduct the ANOVA and obtain solutions.

For the independent analysis of each 30-d interval of $\mathrm{BW}$ and BCS, multiparous cows were combined into a 
single lactation group. Cows were assigned to years of calving, and 2 cows were required for each combination of herd, lactation group, year of calving, and breed of sire. This edit resulted in the removal of 1 pure HO cow in first lactation during interval 7 , and an average of 4 MO-sired cows and 1 pure HO cow in second-throughfifth lactations across 6 other intervals. Numbers of cows analyzed for BW and BCS intervals decreased throughout lactation because some cows left the herd before 300 DIM. The total number of observations analyzed in interval 1 were 175 for $\mathrm{MO} \times \mathrm{HO}, 223$ for MO $\times \mathrm{JH}$, and 315 for pure $\mathrm{HO}$, and the total number of observations in interval 10 were 110 for $\mathrm{MO} \times \mathrm{HO}, 150$ for $\mathrm{MO} \times \mathrm{JH}$, and 208 for pure HO. Statistical analysis for the intervals of BW and BCS had the fixed effects of herd, lactation group (primiparous or multiparous), interaction of herd and lactation group, year of calving nested within interaction of herd and lactation group, breed of sire, breed group, and interaction of lactation group and breed group. Cow nested within breed group was defined as a random variable. The MIXED procedure of SAS was used to conduct the ANOVA and obtain solutions.

\section{RESULTS AND DISCUSSION}

\section{Production and SCS}

The 305-d milk, fat, protein, and fat-plus-protein production differed for the 2 herds because of a difference in the energy content of the feed consumed by cows. Cows increased production with increasing lactation number in both herds, and most effects, including herd, lactation number, interaction of herd and lactation number year of calving nested within interaction of herd and lactation number, and interaction of herd and breed group, differed significantly for the production traits.

For 305-d fluid volume of milk, the 2-breed MO $\times$ $\mathrm{HO}$ crossbreds and the pure HO cows, respectively, were not significantly different for first (7,561 vs. 7,901 $\mathrm{kg}$ ), second (9, 142 vs. $9,179 \mathrm{~kg}$ ), and third-to-fifth (9,949 vs. $10,012 \mathrm{~kg}$ ) lactation across both herds. The $\mathrm{MO} \times \mathrm{JH}$ cows had significantly less $(P<0.05)$ fluid milk production than the pure $\mathrm{HO}$ cows during first $(-781 \mathrm{~kg})$, second $(-420 \mathrm{~kg})$, and third-through-fifth $(-913 \mathrm{~kg})$ lactation, and they also had significantly less $(P<0.05)$ milk volume than $\mathrm{MO} \times \mathrm{HO}$ cows during third-through-fifth lactation $(-850 \mathrm{~kg})$. Milk payment for both herds was based on kilograms of solids in the milk (Hazel et al., 2013), and milk with higher water content may result in a penalty after hauling charges are assessed (Cole et al., 2009b). Therefore, the potentially lower fluid volume of $\mathrm{MO} \times \mathrm{JH}$ crossbred cows should not disqualify the Jersey breed for consideration for crossbreeding.

Production of fat plus protein across herds and lactation groups did not differ $(P=0.30)$ for $\mathrm{MO} \times \mathrm{HO}$ $(585 \mathrm{~kg}), \mathrm{MO} \times \mathrm{JH}(573 \mathrm{~kg})$, and pure $\mathrm{HO}(585 \mathrm{~kg})$ cows. Table 3 has fat-plus-protein production of breed groups by herd and lactation number. Across herds, $\mathrm{MO} \times \mathrm{HO}$ cows were never different from pure $\mathrm{HO}$ cows, and $\mathrm{MO} \times \mathrm{JH}$ cows were different $(P<0.05)$ from pure $\mathrm{HO}$ cows only for fat-plus-protein production during first lactation (495 and $518 \mathrm{~kg}$, respectively). These results are consistent with Walsh et al. (2008), who observed that production of milk, SCM, fat, and protein did not significantly differ for $\mathrm{MO} \times \mathrm{HO}$ and pure HO cows. Heins and Hansen (2012) observed 3\% less fat-plus-protein production for $\mathrm{MO} \times \mathrm{HO}$ compared with pure HO cows. However, they pointed out the MO-sired cows were disadvantaged because the mean rank of sires within breed for production EBV was lower for MO bulls compared with pure HO bulls in that study.

The interaction of herd and breed group was significant for fat-plus-protein production $(P=0.02)$ in this study, and $\mathrm{MO} \times \mathrm{JH}$ cows were more similar to pure HO for fat-plus-protein production in the seasonal pasture herd than in the confinement herd. Crossbreds containing Jersey are often viewed favorably in environments that permit use of pasture because JH crossbred cows have greater fat content of their milk, enhanced fertility and calving ability, and superior profitability compared with pure HO cows (Lopez-Villalobos et al., 2000; Dillon et al., 2007; Pyman, 2007). However, Heins et al. (2011) reported that JH cows had shortcomings in a high-production herd due to lower kilograms of fatplus-protein production during second and third lactation and greater culling for udder conformation for $\mathrm{JH}$ compared with pure HO cows. Vance et al. (2012) compared $\mathrm{JH}$ and pure $\mathrm{HO}$ cows in a confinement versus a pasture-based system, and interaction of breed group and management system was significant only for milk production. Other studies, which investigated milk, fat, and protein production, SCS, and calving interval, concluded that expression of heterosis is usually similar across levels of nutritional or management intensity (Walsh et al., 2008; Kargo et al., 2012; de Haas et al., 2013; Vance et al., 2013).

The MO-sired crossbred cows (2.80) tended $(P=$ $0.08)$ to have lower SCS than pure HO cows (3.02) across the first 5 lactations and across herds. Interaction of herd and breed group was not significant $(P=$ 0.27 ). Breed groups were similar for SCS during first $(2.85,2.83$, and 2.78), and third-through-fifth (3.05, 3.13 , and 3.42) lactations for $\mathrm{MO} \times \mathrm{HO}, \mathrm{MO} \times \mathrm{JH}$, and pure HO cows, respectively. In second lactation, 
Table 3. Least squares means and SE for 305-d fat-plus-protein production (kg) for breed groups

\begin{tabular}{|c|c|c|c|c|c|c|c|c|c|}
\hline \multirow{2}{*}{$\begin{array}{l}\text { Herd and } \\
\text { lactation number }\end{array}$} & \multicolumn{3}{|c|}{ Pure Holstein } & \multicolumn{3}{|c|}{$\begin{array}{l}\text { Montbéliarde } \\
\times \text { Holstein }\end{array}$} & \multicolumn{3}{|c|}{$\begin{aligned} & \text { Montbéliarde } \\
\times & \text { Jersey/Holstein }\end{aligned}$} \\
\hline & $\mathrm{n}$ & LSM & SEM & $\mathrm{n}$ & LSM & SEM & $\mathrm{n}$ & LSM & SEM \\
\hline 1 & 162 & $518^{\mathrm{a}}$ & 6.1 & 59 & $509^{\mathrm{ab}}$ & 10.9 & 90 & $495^{\mathrm{b}}$ & 8.4 \\
\hline 2 & 107 & $596^{\mathrm{a}}$ & 7.3 & 47 & $603^{\mathrm{a}}$ & 12.2 & 73 & $601^{\mathrm{a}}$ & 9.3 \\
\hline $3-5$ & 72 & $641^{\mathrm{a}}$ & 9.4 & 77 & $643^{\mathrm{a}}$ & 10.8 & 82 & $623^{\mathrm{a}}$ & 9.7 \\
\hline \multicolumn{10}{|c|}{ Confinement herd (St. Paul, MN) } \\
\hline 1 & 76 & $622^{\mathrm{a}}$ & 8.8 & 33 & $606^{\mathrm{ab}}$ & 14.7 & 45 & $580^{\mathrm{b}}$ & 11.9 \\
\hline 2 & 61 & $687^{\mathrm{a}}$ & 9.7 & 27 & $676^{\mathrm{a}}$ & 16.0 & 39 & $666^{\mathrm{a}}$ & 12.6 \\
\hline $3-5$ & 43 & $742^{\mathrm{a}}$ & 11.9 & 51 & $714^{\mathrm{ab}}$ & 12.9 & 38 & $704^{\mathrm{b}}$ & 13.9 \\
\hline Across lactations & 180 & $684^{\mathrm{a}}$ & 7.4 & 111 & $665^{\mathrm{ab}}$ & 11.0 & 122 & $650^{\mathrm{b}}$ & 9.5 \\
\hline \multicolumn{10}{|c|}{ Seasonal pasture herd (Morris, MN) } \\
\hline 1 & 86 & $413^{\mathrm{a}}$ & 8.3 & 26 & $411^{\mathrm{a}}$ & 16.0 & 45 & $411^{\mathrm{a}}$ & 11.7 \\
\hline 2 & 46 & $506^{\mathrm{a}}$ & 10.9 & 20 & $530^{\mathrm{a}}$ & 18.3 & 34 & $537^{\mathrm{a}}$ & 13.5 \\
\hline
\end{tabular}

${ }^{\mathrm{a}, \mathrm{b}}$ Means within a row with different superscript letters differ $(P<0.05)$.

however, MO $\times$ HO cows $(2.37)$ had lower $(P<0.05)$ SCS than MO $\times \mathrm{JH}(2.57)$ and pure HO (2.87) cows. The results are similar to those of Heins and Hansen (2012), who reported that MO $\times$ HO had lower $(P$ $<0.05)$ SCS during first, fourth, and fifth lactations compared with pure $\mathrm{HO}$ cows.

\section{Fertility}

Year of calving nested within herd and lactation number was the only statistically significant effect among the non-breed effects for both CR and DO. The CR and DO were not different $(P=0.09$ and 0.10 , respectively) between the 2 herds, which was not surprising because timed AI synchronization was used for all AI services in the confinement herd and most cows were AI bred from synchronized standing heats in the seasonal pasture herd. For breed groups, $\mathrm{MO} \times \mathrm{HO}$ and $\mathrm{MO} \times \mathrm{JH}$ cows had significantly $(P<0.01)$ higher $\mathrm{CR}$ and fewer DO (Table 4) than pure HO cows, and the magnitude of the advantage was about $20 \%$ higher $\mathrm{CR}$ and 5 to $6 \mathrm{wk}$ fewer DO. Kearney et al. (2004) reported heterosis for fertility was expressed similarly across various management systems. Results from the current study support
Kearney et al. (2004), because the interaction of herd and breed group was not significant for either CR or DO $(P>0.08)$ and MO-sired crossbred cows had large advantages for $\mathrm{CR}$ and $\mathrm{DO}$ in both herds.

The MO-sired crossbreds also had a pronounced advantage $(P<0.01)$ over the pure $\mathrm{HO}$ cows for $\mathrm{PR}$ across herds (Table 5). The MO $\times$ HO had an advantage of $+8.7 \%$ to $+13.9 \%$ greater $\mathrm{PR}$, and $\mathrm{MO} \times \mathrm{JH}$ cows had $+10.3 \%$ to $+16.3 \%$ greater PR versus pure HO cows across lactation groups. Across all lactations of cows, the $\mathrm{MO} \times \mathrm{HO}(2$-breed $)$ and the $\mathrm{MO} \times \mathrm{JH}(3$-breed $)$ crossbreds had significantly $(P<0.01)$ greater $\mathrm{PR}$ $(+10.8$ and $+12.8 \%$, respectively) than pure HO cows, and the PR of the MO-sired crossbreds was almost double the PR of the pure HO cows in this study.

An advantage of $\mathrm{PR}$ as a measure of fertility is its ability to capture the pregnancy status of cows as they complete lactations. In this study, $17 \%$ of MO-sired crossbred and $32 \%$ of pure HO lactations ended without a pregnancy because they either left the herd without a confirmed pregnancy or were involuntarily culled for fertility. Differences of this magnitude for CR, DO, or PR of cows in both herds could contribute to improved profitability, because MO-sired crossbred cows were less

Table 4. Least squares means and SE for first-service conception rate (CR) and days open (DO) across lactations and herds for breed groups

\begin{tabular}{|c|c|c|c|c|c|c|c|c|c|}
\hline \multirow[b]{2}{*}{ Trait } & \multicolumn{3}{|c|}{ Pure Holstein } & \multicolumn{3}{|c|}{$\begin{array}{l}\text { Montbéliarde } \\
\times \text { Holstein }\end{array}$} & \multicolumn{3}{|c|}{$\begin{aligned} & \text { Montbéliarde } \\
& \times \text { Jersey/Holstein } \\
&\end{aligned}$} \\
\hline & $\mathrm{n}$ & LSM & SEM & $\mathrm{n}$ & LSM & SEM & $\mathrm{n}$ & LSM & SEM \\
\hline CR (\%) & 312 & $26.9^{\mathrm{a}}$ & 4.20 & 172 & $45.1^{\mathrm{b}}$ & 4.43 & 223 & $49.9^{\mathrm{b}}$ & 3.68 \\
\hline $\mathrm{DO}(\mathrm{d})$ & 259 & $167^{\mathrm{a}}$ & 5.2 & 154 & $128^{\mathrm{b}}$ & 7.1 & 186 & $124^{\mathrm{b}}$ & 6.0 \\
\hline
\end{tabular}

a,b Means within a row with different superscript letters differ $(P<0.05)$. 
Table 5. Pregnancy $\operatorname{rate}^{1}$ (\%, with number of lactations in parentheses) for breed groups

\begin{tabular}{lccc}
\hline & \multicolumn{3}{c}{ Breed } \\
\cline { 2 - 4 } $\begin{array}{l}\text { Lactation } \\
\text { number }\end{array}$ & $\begin{array}{c}\text { Pure } \\
\text { Holstein }\end{array}$ & $\begin{array}{c}\text { Montbéliarde } \\
\times \text { Holstein }\end{array}$ & $\begin{array}{c}\text { Montbéliarde } \\
\times \text { Jersey/Holstein }\end{array}$ \\
\hline 1 & $12.0^{\mathrm{a}}(161)$ & $21.7^{\mathrm{b}}(59)$ & $28.3^{\mathrm{b}}(85)$ \\
2 & $10.9^{\mathrm{a}}(104)$ & $19.6^{\mathrm{b}}(48)$ & $21.2^{\mathrm{b}}(72)$ \\
$3-5$ & $13.4^{\mathrm{a}}(68)$ & $27.3^{\mathrm{b}}(72)$ & $24.9^{\mathrm{b}}(78)$ \\
Combined & $12.1^{\mathrm{a}}(333)$ & $22.9^{\mathrm{b}}(172)$ & $24.9^{\mathrm{b}}(235)$ \\
\hline
\end{tabular}

${ }^{\mathrm{a}, \mathrm{b}}$ Means within a row with different superscript letters $\operatorname{differ}(P<$ $0.05)$.

${ }^{1}$ Pregnancy rate $=$ the number of cows that became pregnant divided by the number of cows eligible to become pregnant during a 21-d estrous cycle.

frequently culled for infertility and had shorter calving intervals than pure $\mathrm{HO}$ cows. If each additional DO is assigned a loss of $\$ 1.50$ (Cole et al., 2009b), the 39-d fewer $\mathrm{DO}$ of $\mathrm{MO} \times \mathrm{HO}$ and the 43 -d fewer $\mathrm{DO}$ of $\mathrm{MO}$ $\times \mathrm{JH}$ cows provides a profit advantage of $\$ 58.50$ and $\$ 64.50$, respectively, per lactation from fertility.

\section{Mortality Rate and Survival}

The confinement herd (14.8\%) and the seasonal pasture herd $(11.2 \%)$ experienced a similar $(P=0.61)$ mortality rate across breed groups; however, seasonal pasture herds typically have reduced death loss compared with other housing systems (Burow et al., 2011; Dechow et al., 2012; Mee, 2012), and this may be because exercise improves the general health of cows (Gustafson, 1993). Mortality rate for the seasonal pasture herd in this study may have been greater than expected because (1) mortalities due to injury may have been higher than for most seasonal pasture herds and (2) some cows were likely euthanized that may have otherwise been acceptable for slaughter because of high hauling cost to the nearest cattle market.
Breed of sire was the only significant effect for mortality rate in the present study. The odds ratios from logistic regression analysis revealed that pure $\mathrm{HO}$ cows were 2.1 times more likely to die on farm than MOsired crossbred cows during their lifetimes. The MO $\times$ HO $(5.1 \%)$ had significantly lower $(P<0.05)$ mortality rate than pure $\mathrm{HO}(17.7 \%)$ cows (Table 6$)$. However, $\mathrm{MO} \times \mathrm{JH}(11.7 \%)$ were not statistically different from pure $\mathrm{HO}$ cows because standard errors for $\mathrm{MO} \times \mathrm{JH}$ were large.

The $17.7 \%$ mortality rate for pure HO in this study is comparable to the $16.5 \%$ reported by Dechow and Goodling (2008) and the $20.6 \%$ found by Pinedo et al. (2010). For national US data, death of cows are likely underreported because some herds fail to report cows that die before their first test day (Heins et al., 2012a). Mortality represents a significant loss of income for dairy producers because salvage value is lost, carcass disposal is costly, future production is lost, and heifer replacement costs may not be recovered (Heins et al., 2012a; Pritchard et al., 2013).

For survival to subsequent calving, significantly $(P<$ 0.04) more cows survived to second, third, and fourth calving for the confinement herd than for the seasonal pasture herd. The difference in survival was likely due to the more stringent culling for fertility of the seasonal pasture herd compared with the confinement herd. For statistical contrasts of the breed groups, $\mathrm{MO} \times \mathrm{HO}$ $(81 \%)$ and $\mathrm{MO} \times \mathrm{JH}(81 \%)$ cows tended $(P<0.09)$ to have greater survival to second calving than pure HO (68\%) cows (Table 6). However, both groups of MO-sired crossbred cows had greater $(P<0.01)$ survival to all of the subsequent lactations than pure $\mathrm{HO}$ cows (Table 6$)$. Significantly $(P<0.01)$ more pure HO cows survived to second calving in the confinement herd than in the seasonal pasture herd (83 vs. $53 \%$, respectively), and a similar result was observed $(P=$ 0.03) for survival of pure $\mathrm{HO}$ cows to third calving

Table 6. Least squares means and SE for mortality rate $^{1}$ and survival to subsequent calving ${ }^{2}$ for breed groups

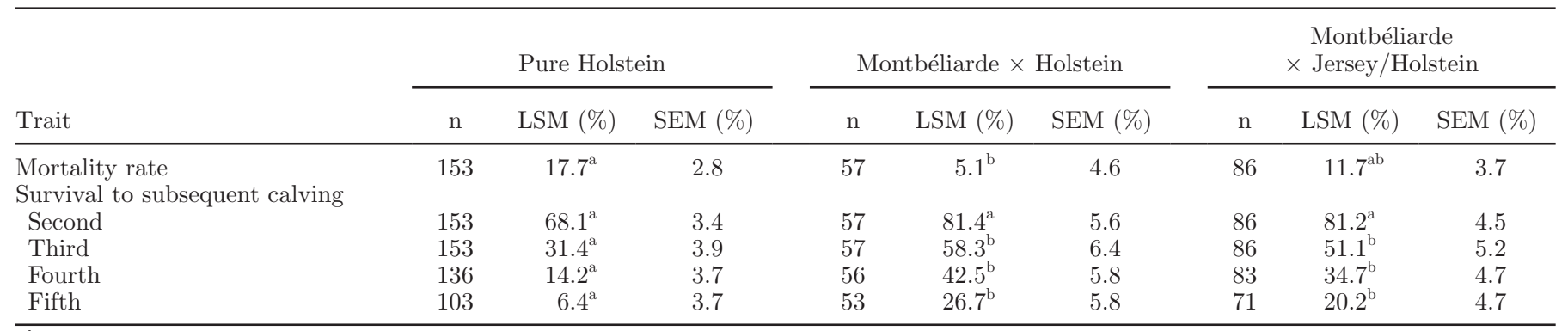

\footnotetext{
$\overline{\mathrm{a}, \mathrm{b}}$ Means within a row with different superscript letters differ $(P<0.05)$.

${ }^{1}$ Mortality rate $=$ number of cows died or euthanized divided by total number of cows.

${ }^{2}$ Survival to subsequent calving $=$ number of cows that calved divided by the number of cows with opportunity to calve for a subsequent lactation.
} 
Table 7. Least squares means and SE for body measurements across lactations and herds for breed groups

\begin{tabular}{|c|c|c|c|c|c|c|c|c|c|}
\hline \multirow[b]{2}{*}{ Trait } & \multicolumn{3}{|c|}{ Pure Holstein } & \multicolumn{3}{|c|}{ Montbéliarde $\times$ Holstein } & \multicolumn{3}{|c|}{$\begin{aligned} & \text { Montbéliarde } \\
\times & \text { Jersey/Holstein }\end{aligned}$} \\
\hline & $\mathrm{n}^{1}$ & LSM & SEM & $\mathrm{n}^{1}$ & LSM & SEM & $\mathrm{n}^{1}$ & LSM & SEM \\
\hline $\mathrm{BW}(\mathrm{kg})$ & 320 & $572^{\mathrm{a}}$ & 4.2 & 176 & $611^{\mathrm{b}}$ & 6.6 & 226 & $554^{\mathrm{c}}$ & 5.3 \\
\hline $\mathrm{BCS}$ & 320 & $2.87^{\mathrm{a}}$ & 0.02 & 176 & $3.36^{\mathrm{b}}$ & 0.03 & 226 & $3.33^{\mathrm{b}}$ & 0.03 \\
\hline Heart girth $(\mathrm{cm})$ & 309 & $197.7^{\mathrm{a}}$ & 0.6 & 166 & $198.2^{\mathrm{a}}$ & 0.9 & 216 & $191.4^{\mathrm{b}}$ & 0.7 \\
\hline Front teat width $(\mathrm{cm})$ & 309 & $14.6^{\mathrm{a}}$ & 0.3 & 167 & $16.9^{\mathrm{b}}$ & 0.5 & 217 & $17.5^{\mathrm{b}}$ & 0.4 \\
\hline Front teat length $(\mathrm{cm})$ & 309 & $4.9^{\mathrm{a}}$ & 0.07 & 167 & $5.1^{\mathrm{a}}$ & 0.11 & 217 & $5.1^{\mathrm{a}}$ & 0.09 \\
\hline
\end{tabular}

(40 vs. $23 \%$, respectively) for the 2 herds. The reduced survival of pure $\mathrm{HO}$ cows in the seasonal pasture herd appeared to be heavily influenced by the poor fertility of pure $\mathrm{HO}$ cows. When $\mathrm{MO} \times \mathrm{HO}$ and pure $\mathrm{HO}$ cows were compared in a pasture environment by Walsh et al. (2008), the pure HO cows survived only 1.9 lactations, compared with 3.8 lactations for $\mathrm{MO} \times \mathrm{HO}$ cows. Washburn (2009) suggested that the poor survival of pure $\mathrm{HO}$ cows in pasture herds may be the driving factor for the increased use of crossbreeding among pasture herds in the United States.

\section{Longevity and Lifetime Production}

Longevity of cows is an important factor in profit calculations, because a large expense for dairy herds is growing replacement heifers. The $\mathrm{MO} \times \mathrm{HO}$ cows in the present study had longevity of $973 \mathrm{~d}$ compared with $747 \mathrm{~d}$ for pure $\mathrm{HO}$ cows across herds when a 4-yr maximum for survival after first calving was enforced. For that 4-yr interval, $\mathrm{MO} \times \mathrm{HO}$ cows had significantly greater $(P<0.01)$ lifetime fat-plus-protein production than the pure HO cows (1,609 vs. 1,201 kg), which was anticipated because the $\mathrm{MO} \times \mathrm{HO}$ cows calved more frequently during their lifetimes and, consequently, had more days at peak production. The $\mathrm{MO} \times \mathrm{JH}$ cows had greater $(P<0.05)$ longevity $(884 \mathrm{~d})$ than pure HO cows $(746 \mathrm{~d})$, but fat-plus-protein production (1,389 $\mathrm{kg}$ ) was similar to pure HO cows $(1,201 \mathrm{~kg})$ during the same 4-yr period after first calving. The MO-sired crossbreds had a greater number of calves born, because they calved more frequently than pure HO cows. Results from this study emulate those of Heins et al. (2012a), who reported that MO $\times \mathrm{HO}$ cows had $+213 \mathrm{~d}$ greater longevity and $+401 \mathrm{~kg}$ of fat plus protein when data was limited to the first $4 \mathrm{yr}$ in the herd. Walsh et al. (2008) reported that median days of longevity were
$+690 \mathrm{~d}$ greater and +1.9 lactations longer for $\mathrm{MO} \times$ $\mathrm{HO}$ compared with pure $\mathrm{HO}$ cows.

\section{Body Measurements}

$\boldsymbol{H} \boldsymbol{H}, \boldsymbol{B} \boldsymbol{W}, \boldsymbol{B C S}$, and $\boldsymbol{H G}$. Lactation number, year of calving nested within herd and lactation number, and breed group differed significantly $(P<0.01)$ for $\mathrm{HH}$. For breed groups across herds (Table 7), MO $\times$ $\mathrm{HO}$ did not differ from pure $\mathrm{HO}$ for $\mathrm{HH}$ during any lactation number or across lactations. However, $\mathrm{MO} \times$ JH cows had significantly $(P<0.01)$ shorter HH than either $\mathrm{MO} \times \mathrm{HO}$ or pure $\mathrm{HO}$ cows for first, second, and third-through-fifth lactations. The shorter $\mathrm{HH}$ of MO $\times$ JH cows was expected because Heins et al. (2011) reported that $\mathrm{JH}$ cows had 8.8 to $9.4 \mathrm{~cm}$ shorter $\mathrm{HH}$ than pure $\mathrm{HO}$ cows during their first 3 lactations.

All effects of herd, lactation number, their interaction, year of calving nested within herd and lactation, and breed group differed significantly for BW. Across breed groups, cows in the confinement herd had greater BW in first $(+66 \mathrm{~kg})$, second $(+44 \mathrm{~kg})$, and third-through-fifth $(+66 \mathrm{~kg})$ lactation than cows in the seasonal pasture herd, and this was likely a result of the greater energy level of diets fed to cows in the confinement herd. The $\mathrm{MO} \times \mathrm{HO}$ had significantly greater $(P<0.01) \mathrm{BW}$ across lactations compared with pure HO cows (Table 7 ) and also within each lactation number. However, the $\mathrm{MO} \times \mathrm{JH}$ cows were not different $(P=0.25)$ from pure HO cows for BW in first lactation, tended $(P=0.08)$ to be heavier in second lactation $(+25 \mathrm{~kg})$, and were significantly lighter $(-30 \mathrm{~kg})$ than pure $\mathrm{HO}$ in third-tofifth lactations. Across lactations, the $\mathrm{MO} \times \mathrm{JH}$ cows had less $\mathrm{BW}$ than either $\mathrm{MO} \times \mathrm{HO}$ or pure $\mathrm{HO}$ cows. The interaction of lactation number and breed group was not significant $(P=0.07)$, and least squares means of BW for breed groups by lactation number revealed 
that $\mathrm{MO} \times \mathrm{HO}, \mathrm{MO} \times \mathrm{JH}$, and pure $\mathrm{HO}$ cows all had similar increases from first to second lactation $(+59$, +52 , and $+58 \mathrm{~kg}$, respectively) and also from second lactation to third-through-fifth lactations $(+52,+38$, and $+53 \mathrm{~kg}$, respectively). Therefore, breed groups appeared to increase in $\mathrm{BW}$ at similar rates during their lifetimes.

For the analysis of BW for the 10 intervals across lactation, $\mathrm{MO} \times \mathrm{HO}$ cows had significantly $(P<0.01)$ greater $\mathrm{BW}$ than $\mathrm{MO} \times \mathrm{JH}$ and pure $\mathrm{HO}$ cows in all 10 intervals for both primiparous and multiparous lactation groups. On the other hand, $\mathrm{MO} \times \mathrm{JH}$ cows were not different from pure $\mathrm{HO}$ in any interval for first lactation and, in second-and-later lactations, $\mathrm{MO} \times$ JH cows had significantly $(P<0.05)$ less BW than pure HO cows during intervals $1,3,4,5,7$, and 8 . All contrasts for BW between breeds for each of the first 4 intervals were conducted within each lactation group (36 comparisons in total) to assess rate of loss in BW during early lactation, and 35 of those contrasts were nonsignificant $(P>0.05)$. Therefore, results from this study suggest that $\mathrm{MO} \times \mathrm{HO}$ cows carried greater BW throughout their lactations compared with both the $\mathrm{MO} \times \mathrm{JH}$ and pure $\mathrm{HO}$ cows. However, lactation curves for BW did not differ in shape for the breed groups.

Among the fixed effects for BCS, only herd, interaction of herd and lactation number, year of calving nested within herd and lactation number, and breed group differed significantly $(P<0.01)$. Cows in the seasonal pasture herd had lower BCS (3.00) than cows in the confinement herd (3.21) across lactations and breed groups, which was likely the cause of the lower BW for cows in the seasonal pasture herd. The $\mathrm{MO} \times \mathrm{HO}$ (3.36) and $\mathrm{MO} \times \mathrm{JH}$ crossbred cows (3.33) had greater BCS than pure HO cows (2.87) across herds and lactations (Table 7 ), and the $\mathrm{MO} \times \mathrm{HO}$ and $\mathrm{MO} \times \mathrm{JH}$ cows had significantly greater $(P<0.01)$ BCS than pure HO cows during each lactation. For the 10 intervals of BCS throughout lactation, the MO-sired crossbred cows had significantly $(P<0.01)$ greater BCS in every interval for both primiparous and multiparous lactation groups. The $\mathrm{MO} \times \mathrm{HO}$ in second-and-greater lactations had significantly $(P<0.05)$ greater $\mathrm{BCS}$ than $\mathrm{MO} \times \mathrm{JH}$ cows only during intervals 3,8 , and 10 . Change in BCS during the first 4 intervals was compared between the 3 breed groups, but 34 of 36 contrasts were not significantly different $(P>0.05)$. Results from change in BCS during early lactation reveal that all cows lost BCS in early lactation, which agrees with results of Walsh et al. (2008). The rate of loss of BCS was similar for breed groups, and MO-sired crossbreds maintained greater BCS throughout lactation because they had greater precalving BCS.
Perhaps, the greater BCS of MO-sired crossbred cows partially explains the substantial advantages for fertility and survival of MO-sired crossbred cows over pure HO cows in this study, because the relationships of BCS with both fertility and health have been well documented within the HO breed (Zwald et al., 2004; Banos and Coffey, 2010). Mendonça et al. (2013) credited heterosis, breed differences, or both of these factors for the improved immunity and decreased incidence of health disorders of MO-sired crossbred versus pure $\mathrm{HO}$ cows. However, the greater BCS of MO-sired crossbreds compared with pure HO cows could also be a contributing factor to the improved health and fertility of MO-sired crossbreds because greater BCS is linked to enhanced health and fertility in observations of pure HO cows (Pryce et al., 2001; Loker et al., 2012).

For HG, the fixed effects of herd, lactation number, year of calving nested within herd and lactation, breed group, and interaction of lactation number and breed group were all significant $(P<0.01)$. Least squares means of HG for cows in the confinement herd (198.9 $\mathrm{cm})$ were significantly $(P<0.01)$ larger than for cows in the seasonal pasture herd $(193.6 \mathrm{~cm})$, and HG of cows increased with lactation number, as expected. Across lactations, $\mathrm{MO} \times \mathrm{HO}$ and pure $\mathrm{HO}$ cows did not differ for HG $(P>0.31$; Table 7$)$ despite the significantly $(P<0.01)$ greater $\mathrm{BW}$ of $\mathrm{MO} \times \mathrm{HO}$ cows during all lactations. On the other hand, $\mathrm{HG}$ of $\mathrm{MO} \times \mathrm{JH}$ was smaller $(P<0.01)$ than both $\mathrm{MO} \times \mathrm{HO}$ and pure $\mathrm{HO}$ cows across lactations (Table 7 ). The lack of difference in $\mathrm{HG}$ of $\mathrm{MO} \times \mathrm{HO}$ and pure $\mathrm{HO}$ cows and the smaller $\mathrm{HG}$ of $\mathrm{MO} \times \mathrm{JH}$ cows was surprising because $\mathrm{BW}$ and HG often have high correlation within the HO breed. Perhaps, proportionality of body dimensions differ for MO-sired crossbred cows versus pure $\mathrm{HO}$ cows.

$\boldsymbol{F A N G L}$ and $\boldsymbol{H L}$. For FANGL and HL, almost all fixed effects in the model differed significantly $(P$ $<0.05)$. Time on pasture is beneficial for hoof conformation and health (Haskell et al., 2006) and, as expected, cows in the seasonal pasture herd had both steeper FANGL $\left(+1.4^{\circ}\right)$ and shorter HL $(-0.11 \mathrm{~cm})$ than cows in the confinement herd. The $\mathrm{MO} \times \mathrm{HO}$ had significantly $(P<0.01)$ steeper FANGL $\left(+1.8^{\circ}\right)$ and significantly $(P<0.01)$ shorter HL $(-0.2 \mathrm{~cm})$ than the pure $\mathrm{HO}$ cows across lactations (Table 7 ). The MO $\times$ JH were not different $(P>0.16)$ for either FANGL or HL compared with pure HO cows. However, among the MO-sired crossbreds, $\mathrm{MO} \times \mathrm{HO}$ had significantly $(P$ $<0.05)$ steeper FANGL $\left(+1.7^{\circ}\right)$ than MO $\times \mathrm{JH}$ cows, which was not surprising because FANGL of the JH crossbred dams of cows in the current study was -1.3 to $-1.8^{\circ}$ lower than the pure HO cows (Heins et al., 2011). Dairy producers perceive cows with steeper FANGL to have fewer hoof disorders, but the correlation between 
hoof disorders and feet and leg conformation is often nonsignificant (Häggman and Juga, 2013). Therefore, future comparisons of MO-sired crossbred and pure $\mathrm{HO}$ cows should focus on incidence of lameness and hoof disorders rather than hoof measurements.

Udder. The effects of lactation number, interaction of herd and lactation number, and year of calving nested within herd and lactation number were significant $(P<$ 0.05 ) for all udder measurements, except interaction of herd and lactation number was not significant for TL. The fixed effect of herd was significant only for TW, and cows in the confinement herd had greater distance for TW $(+2.1 \mathrm{~cm})$ compared with cows in the seasonal pasture herd. The greater TW for cows in the confinement herd was likely a result of the higher production levels of those cows because they were fed a TMR diet year-round, whereas the cows in the seasonal pasture herd were on pasture during summer when udder measurements were collected.

The MO-sired crossbreds had significantly less UC than the pure $\mathrm{HO}$ cows during each lactation and, across lactations, the $\mathrm{MO} \times \mathrm{HO}(-2.6 \mathrm{~cm})$ had significantly $(P<0.01)$ less UC than pure HO cows (Table $7)$. The MO $\times \mathrm{JH}$ had significantly $(P<0.03)$ less UC than both the $\mathrm{MO} \times \mathrm{HO}$ and pure $\mathrm{HO}$ cows $(-2.1$ and $-4.7 \mathrm{~cm}$, respectively) across lactations. Interaction of lactation number and breed group was not significant $(P=0.72)$ for $\mathrm{UC}$; therefore, regardless of breed group, udders became deeper with increasing lactation number at approximately the same rate. Only a single cow from each of the 3 breed groups was culled for udder conformation in this study, but more $\mathrm{MO} \times \mathrm{HO}$ and $\mathrm{MO} \times \mathrm{JH}$ cows survived to third, fourth, and fifth calvings than pure HO cows. Consequently, evidence did not exist to suggest that the $-3.8-\mathrm{cm}$ less $\mathrm{UC}$ of MO-sired crossbreds across lactations and breed groups resulted in increased culling of cows. Conversely, Heins et al. (2011) reported that the -8.5 to $-9.0 \mathrm{~cm}$ less UC of JH cows during second and third lactations caused significantly more JH cows to be culled for udder conformation than pure $\mathrm{HO}$ cows in that study.

The TW was significantly greater for both $\mathrm{MO} \times$ $\mathrm{HO}(+2.3 \mathrm{~cm})$ and $\mathrm{MO} \times \mathrm{JH}(+2.9 \mathrm{~cm})$ across lactations than the pure HO cows. However, TL was not significantly different for $\mathrm{MO} \times \mathrm{HO}$ and $\mathrm{MO} \times \mathrm{JH}$ versus pure HO cows (Table 7). Traditionally, dairy producers have selected cows with greater UC and less TW (Miglior et al., 2005; Shook, 2006), and significant selection for udder conformation of pure HO cows has resulted in shallower udders and closer front and rear teat placement for first-lactation cows (Shook, 2006; VanRaden et al., 2009). However, rear teats that are too close are a concern for milking ability, especially for the increasing number of cows milked with robotic sys- tems. Miller et al. (1995) reported $12 \%$ of first-lactation pure HO cows that were milked by a robotic milking system had failure of cluster attachment due to close rear teat placement.

\section{CONCLUSIONS}

The MO-sired crossbred cows in this study did not significantly differ from pure HO cows for fat-plus-protein production across herds and lactations. The similar production for the breed groups may have resulted from genetic improvement within the $\mathrm{HO}$ and $\mathrm{MO}$ breeds, heterosis when breeds are crossed, or a combination of these 2 factors. More importantly, the MO-sired crossbreds were much superior to pure $\mathrm{HO}$ cows for fertility, mortality rate, survival to subsequent calving, and longevity. Some of the superiority for fertility and longevity of the MO-sired crossbreds compared with pure $\mathrm{HO}$ cows in this study may have resulted from the greater $\mathrm{BCS}$ of the MO-sired crossbreds. A breeding objective of the MO breed in France has continuously been to place emphasis on maintaining BCS, which is contrary to the breeding objective of the HO breed to increase angularity. Results of this study indicated that MO-sired crossbred cows had similar production to pure HO cows, but the MO-sired crossbred cows had advantages over pure HO cows for fertility, survival, and longevity in both a confinement and a seasonal pasture herd. Three-breed rotational crossbreeding using purebred bulls from distinct dairy breeds is the most common approach currently being recommended and used for commercial milk production. The 3 breeds must be complementary to each other, and they must be well suited to specific management systems. The alternative combinations of dairy breeds for crossbreeding have not yet been examined across management systems and warrant further research.

\section{ACKNOWLEDGMENTS}

The authors express gratitude to Bill Hansen and coworkers at the St. Paul, Minnesota, dairy facility and Dennis Johnson, Darin Huot, and coworkers at the West Central Research and Outreach Center (Morris, Minnesota) for their assistance in data collection and care of animals. Supplemental funding for this project was provided by Coopex Montbéliarde (Roulans, France).

\section{REFERENCES}

Banos, G., and M. P. Coffey. 2010. Genetic association between body energy measured throughout lactation and fertility in dairy cattle. Animal 4:189-199.

Bjelland, D. W., K. A. Weigel, N. Vukasinovic, and J. D. Nkrumah. 2013. Evaluation of inbreeding depression in Holstein cattle using 
whole-genome SNP markers and alternative measures of genomic inbreeding. J. Dairy Sci. 96:4697-4706.

Burow, E., P. T. Thomsen, J. T. Sørensen, and T. Rousing. 2011. The effect of grazing on cow mortality in Danish dairy herds. Prev. Vet. Med. 100:237-241.

Cole, J. B., D. J. Null, and P. M. VanRaden. 2009a. Best prediction of yields for long lactations. J. Dairy Sci. 92:1796-1810.

Cole, J. B., P. M. VanRaden, and Multi-State Project S-1040. 2009b. Net merit as a measure of lifetime profit: 2010 revision. Accessed Oct. 30, 2013. http://aipl.arsusda.gov/reference/nmcalc.htm.

Council on Dairy Cattle Breeding. 2013. Trend in inbreeding coefficients for Holstein or Red \& White. Accessed Dec. 17, 2013. https://www.cdcb.us/eval/summary/inbrd.cfm.

de Haas, Y., E. A. A. Smolders, J. N. Hoorneman, W. J. Nauta, and R. F. Veerkamp. 2013. Suitability of cross-bred cows for organic farms based on cross-breeding effects on production and functional traits. Animal 7:655-665.

de Vries, A., C. Steenholdt, and C. A. Risco. 2005. Pregnancy rates and milk production in natural service and artificially inseminated herds in Florida and Georgia. J. Dairy Sci. 88:948-956.

Dechow, C. D., and R. C. Goodling. 2008. Mortality, culling by 60 days in milk, and production profiles in high- and low-survival Pennsylvania herds. J. Dairy Sci. 91:4630-4639.

Dechow, C. D., R. C. Goodling, and S. P. Rhode. 2012. The effect of sire selection on cow mortality and early lactation culling in adverse and favorable cow survival environments. Prev. Vet. Med. 103:228-233.

Dillon, P., K. Macdonald, C. W. Holmes, N. Lopez-Villalobos, F. Buckley, B. Horan, and D. P. Berry. 2007. Cow genetics for temperate grazing systems. Pages 152-184 in Meeting the Challenges for Pasture-Based Dairying. Proc. Australasian Dairy Science Symposium, University of Melbourne, Australia. D. F. Chapman, D. A. Clark, K. L. MacMillan, D. P. Nation, ed. National Dairy Alliance, Melbourne, Victoria, Australia.

Falconer, D. S., and T. F. C. Mackay. 1996. Introduction to quantitative genetics. 4th ed. Longman House, Harlow, Essex, UK.

Ferguson, J. D., D. T. Galligan, and N. Thomsen. 1994. Principle descriptors of body condition score in Holstein cows. J. Dairy Sci. 77:2695-2703

Gustafson, G. M. 1993. Effects of daily exercise on the health of tied dairy cows. Prev. Vet. Med. 17:209-223.

Häggman, J., and J. Juga. 2013. Genetic parameters for hoof disorders and feet and leg conformation traits in Finnish Holstein cows. J. Dairy Sci. 96:3319-3325.

Hahn, M. V., B. T. McDaniel, and J. C. Wilk. 1984. Genetic and environmental variation of hoof characteristics of Holstein cattle. J. Dairy Sci. 67:2986-2998.

Hansen, L. B. 2000. Consequences of selection for milk yield from a geneticist's viewpoint. J. Dairy Sci. 83:1145-1150.

Hansen, L. B. 2006. Monitoring the worldwide supply for dairy cattle with emphasis on managing crossbreeding and inbreeding. CDROM Commun. No. 01-01 in Proc. 8th World Congress on Genetics Applied to Livestock Production, Belo Horizonte, Minas Gerais, Brazil. Instituto Procienia, Belo Horizonte, Brazil.

Haskell, M. J., L. J. Rennie, V. A. Bowell, M. J. Bell, and A. B. Lawrence. 2006. Housing system, milk production, and zero-grazing effects on lameness and leg injury in dairy cows. J. Dairy Sci. 89:4259-4266

Hazel, A. R., B. J. Heins, A. J. Seykora, and L. B. Hansen. 2013. Montbéliarde-sired crossbreds compared with pure Holsteins for dry matter intake, production, and body traits during the first 150 days of first lactation. J. Dairy Sci. 96:1915-1923.

Heins, B. J., and L. B. Hansen. 2012. Short communication: Fertility, somatic cell score, and production of Normande $\times$ Holstein, Montbéliarde $\times$ Holstein, and Scandinavian Red $\times$ Holstein crossbreds versus pure Holsteins during their first 5 lactations. J. Dairy Sci. 95:918-924.

Heins, B. J., L. B. Hansen, and A. De Vries. 2012a. Survival, lifetime production, and profitability of crossbreds of Holstein with Normande, Montbéliarde, and Scandinavian Red compared to pure Holstein cows. J. Dairy Sci. 95:1011-1021.
Heins, B. J., L. B. Hansen, A. R. Hazel, A. J. Seykora, D. G. Johnson, and J. G. Linn. 2010. Birth traits of pure Holstein calves versus Montbeliarde-sired crossbred calves. J. Dairy Sci. 93:2293-2299.

Heins, B. J., L. B. Hansen, A. R. Hazel, A. J. Seykora, D. G. Johnson, and J. G. Linn. 2012b. Short communication: Jersey $\times$ Holstein crossbreds compared with pure Holsteins for body weight, body condition score, fertility, and survival during the first three lactations. J. Dairy Sci. 95:4130-4135.

Heins, B. J., L. B. Hansen, A. J. Seykora, A. R. Hazel, D. G. Johnson, and J. G. Linn. 2011. Short communication: Jersey $\times$ Holstein crossbreds compared with pure Holsteins for production, mastitis, and body measurements during the first 3 lactations. J. Dairy Sci. 94:501-506.

Henderson, L., F. Miglior, A. Sewalem, J. Wormuth, D. Kelton, A. Robinson, and K. E. Leslie. 2011. Short communication: Genetic parameters for measures of calf health in a population of Holstein calves in New York State. J. Dairy Sci. 94:6181-6187.

Kargo, M., P. Madsen, and E. Norberg. 2012. Short communication: Is crossbreeding only beneficial in herds with low management level? J. Dairy Sci. 95:925-928.

Kearney, J. F., M. M. Schutz, and P. J. Boettcher. 2004. Genotype $\times$ environment interaction for grazing vs. confinement. II. Health and reproduction traits. J. Dairy Sci. 87:510-516.

Leitch, H. W. 1994. Comparison of international selection indices for dairy cattle breeding. Interbull Bull. No. 10. Interbull, Uppsala, Sweden.

Loker, S., F. Miglior, A. Koeck, T. F.-O. Neuenschwander, C. Bastin, J. Jamrozik, L. R. Schaeffer, and D. Kelton. 2012. Relationship between body condition score and health traits in first-lactation Canadian Holsteins. J. Dairy Sci. 95:6770-6780.

Lopez-Villalobos, N., D. J. Garrick, C. W. Holmes, H. T. Blair, and R. J. Spelman. 2000. Profitabilities of some mating systems for dairy herds in New Zealand. J. Dairy Sci. 83:144-153.

Lucy, M. C. 2001. Reproductive loss in high-producing dairy cattle Where will it end? J. Dairy Sci. 84:1277-1293.

Mee, J. F. 2012. Reproductive issues arising from different management systems in the dairy industry. Reprod. Domest. Anim. 47(Suppl. 5):42-50

Mendonça, L. G. D., C. C. Abade, E. M. da Silva, and R. C. Chebel. 2010. Comparison of postpartum health, uterine involution, and resumption of ovarian cycles of Holstein and crossbred dairy cows. J. Dairy Sci. 93(E-Suppl. 1):488. (Abstr.)

Mendonça, L. G. D., N. B. Litherland, M. C. Lucy, D. H. Keisler, M. A. Ballou, L. B. Hansen, and R. C. Chebel. 2013. Comparison of innate immune responses and somatotropic axis components of Holstein and Montbéliarde-sired crossbred dairy cows during the transition period. J. Dairy Sci. 96:3588-3598.

Miglior, F., B. L. Muir, and B. J. Van Doormaal. 2005. Selection indices in Holstein cattle of various countries. J. Dairy Sci. 88:12551263

Miller, R. H., L. A. Fulton, B. Erez, W. F. Williams, and R. E. Pearson. 1995. Variation in distances among teats of Holstein cows: Implications for automated milking. J. Dairy Sci. 78:1456-1462.

O. S. Montbéliarde. 2013. Organisme de Sélection de la Race Montbéliarde. Accessed Oct. 30, 2013. http://www.montbeliarde.org/ race-en.php.

Pinedo, P. J., A. De Vries, and D. W. Webb. 2010. Dynamics of culling risk with disposal codes reported by dairy herd improvement dairy herds. J. Dairy Sci. 93:2250-2261.

Pritchard, T., M. Coffey, R. Mrode, and E. Wall. 2013. Understanding the genetics of survival in dairy cows. J. Dairy Sci. 96:3296-3309.

Pryce, J. E., M. P. Coffey, and G. Simm. 2001. The relationship between body condition score and reproductive performance. J. Dairy Sci. 84:1508-1515.

Pyman, M. F. S. 2007. A comparative study of the productivity, selected health parameters and reproductive performance of Jersey $\times$ Holstein-Friesian crossbred cows in predominantly HolsteinFriesian herds in Victoria. PhD Thesis. Univ. of Melbourne, Victoria, Australia.

Roche, J. R., N. C. Friggens, J. K. Kay, M. W. Fisher, K. J. Stafford, and D. P. Berry. 2009. Invited review: Body condition score and 
its association with dairy cow productivity, health, and welfare. J. Dairy Sci. 92:5769-5801.

SAS Institute. 2008. SAS/STAT Software, Release 9.2. SAS Institute Inc. Cary, NC.

Shook, G. E. 2006. Major advances in determining appropriate selection goals. J. Dairy Sci. 89:1349-1361.

Sørensen, A. C., M. K. Sørensen, and P. Berg. 2005. Inbreeding in Danish dairy cattle breeds. J. Dairy Sci. 88:1865-1872.

Sørensen, M. K., E. Norberg, J. Pedersen, and L. G. Christensen. 2008. Invited review: Crossbreeding in dairy cattle: A Danish perspective. J. Dairy Sci. 91:4116-4128.

Swalve, H. H. 2007. Crossbreeding in dairy cattle: International trends and results from crossbreeding data in Germany. Lohmann Info. 42:38-46.

Vance, E. R., C. P. Ferris, C. T. Elliott, H. M. Hartley, and D. J. Kilpatrick. 2013. Comparison of the performance of Holstein-Friesian and Jersey $\times$ Holstein-Friesian crossbred dairy cows within three contrasting grassland-based systems of milk production. Livest. Sci. 151:66-79.

Vance, E. R. C. P. Ferris, C. T. Elliott, S. A. McGettrick, and D. J. Kilpatrick. 2012. Food intake, milk production, and tissue changes of Holstein-Friesian and Jersey $\times$ Holstein-Friesian dairy cows within a medium-input grazing system and a high-input total confinement system. J. Dairy Sci. 95:1527-1544.
VanRaden, P. M., J. B. Cole, M. E. Tooker, and T. A. Cooper. 2009. Genetic base changes for January 2010. Accessed Oct. 30, 2013 http://aipl.arsusda.gov/reference/base2010.htm.

VanRaden, P. M., and A. H. Sanders. 2003. Economic merit of crossbred and purebred US dairy cattle. J. Dairy Sci. 86:1036-1044.

VanRaden, P. M., A. H. Sanders, M. E. Tooker, R. H. Miller, H. D. Norman, M. T. Kuhn, and G. R. Wiggans. 2004. Development of a national genetic evaluation for cow fertility. J. Dairy Sci. 87:2285-2292.

Walsh, S., F. Buckley, K. Pierce, N. Byrne, J. Patton, and P. Dillon. 2008. Effects of breed and feeding system on milk production, body weight, body condition score, reproductive performance, and postpartum ovarian function. J. Dairy Sci. 91:4401-4413.

Washburn, S. P. 2009. Lessons learned from grazing dairies. Pages 57-68 in Proc. 46th Florida Dairy Prod. Conf., Gainesville, FL. University of Florida, Gainesville.

Weigel, K. A., and K. A. Barlass. 2003. Results of a producer survey regarding crossbreeding on US dairy farms. J. Dairy Sci. $86: 4148-4154$.

Zwald, N. R., K. A. Weigel, Y. M. Chang, R. D. Welper, and J. S. Clay. 2004. Genetic selection for health traits using producerrecorded data. II. Genetic correlations, disease probabilities, and relationships with existing traits. J. Dairy Sci. 87:4295-4302. 